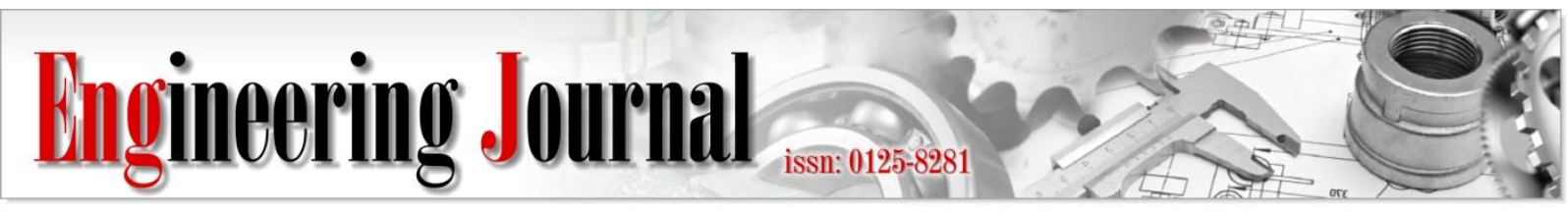

Article

\title{
Mo and Mn Co-doping for Isoproturon Degradation Under Visible Light
}

\author{
Yada Yakob ${ }^{1}$, Kanjana Naknun ${ }^{1}$, Parichat Hirunmas ${ }^{1}$, Paul Egwuonwu Dim ${ }^{2}$, and Mutsee \\ Termtanun $^{1 *}$
}

1 Department of Chemical Engineering, Faculty of Engineering and Industrial Technology, Silpakorn University, Nakhon Pathom, 73000, Thailand

2 Department of Chemical Engineering, School of Infrastructure, Process and Engineering Technology,

Federal University of Technology, Minna, Nigeria

*E-mail: Termtanun_m@su.ac.th (Corresponding author)

\begin{abstract}
This research focused on the improvement of the catalytic efficiency of titanium dioxide using transition metals for isoproturon degradation under visible light. Molybdenum and manganese were varied at $0.5 \%$ by weight and $1 \%$ by weight. Mo/Mn doped $\mathrm{TiO}_{2}$ was synthesized using sol-gel method and compared with the undoped $\mathrm{TiO}_{2}$ to find out the most suitable doping metal and doping amount for the degradation of isoproturon, a pesticide generally used in agricultural sites. The characterization techniques for all doped $\mathrm{TiO}_{2}$ included $\mathrm{N}_{2}$ physical adsorption/desorption (BET), X-Ray diffraction Spectroscopy (XRD), Ultra Violet -Visible Spectroscopy (UV-VIS), Photoluminescence Spectroscopy (PL), and SEM (Scanning Electron Microscope) -EDX (Energy Dispersive X-ray Diffraction). For each $\mathrm{TiO}_{2}$ catalyst, the photocatalytic degradation of $10 \mathrm{ppm}$ isoproturon was carried out under visible light and the catalytic efficiency was determined using UV-VIS to measure the residual concentration of isoproturon. According to the results, doping molybdenum and manganese assists in reducing the band gap energy, increasing the surface area of catalysts, and enhancing the photocatalytic activity. In case of manganese, it also minimizes the recombination of photogenerated electrons and holes, which leads to better photocatalytic performance. The optimum isoproturon degradation is appeared with the co-doped Mo and Mn at 1\% by weight.
\end{abstract}

Keywords: Photocatalytic degradation, sol-gel technique, isoproturon, molybdenum, manganese.

ENGINEERING JOURNAL Volume 25 Issue 2

Received 7 February 2020

Accepted 25 November 2020

Published 28 February 2021

Online at https:/ / engj.org/

DOI:10.4186/ej.2021.25.2.277 


\section{Introduction}

Isoproturon, a herbicide for eliminating biennial grass such as wheat and barley, is highly toxic and easily accumulate in an environment, which is fatal to human and various aqueous creatures even in the minimal amounts. It appears to be acute oral toxicity for rat at approximately $1,800 \mathrm{mg} / \mathrm{kg}$, and acute dermal toxicity for rabbit at greater than $2,000 \mathrm{mg} / \mathrm{kg}$. There is still isoproturon contaminated up to $500 \mathrm{mg}$ per square meter in a residential area, while European union limit drinking water is fixed to $0.1 \mu \mathrm{g} / 1[1]$. One alternative to remove this compound is using photocatalysis in which isoproturon can be decontaminated by $\mathrm{TiO}_{2}$. Generally, titanium dioxide is used as a catalyst in different ways due to its chemical stability, environmentally friendly and inexpensive but an effective working range is only within the ultraviolet light (UV). However, the solar energy is composed of less than 5\% UV [2]. Hence, the improvement of $\mathrm{TiO}_{2}$ catalytic performance has received much attention for organic chemicals treatment under sunlight. There have been several routes to prepare $\mathrm{TiO}_{2}$, for example, sol-gel technique, hydrothermal, flame spray pyrolysis, reverse-micelles template, etc. However, the solgel method is generally used due to its several advantages. By tailoring the chemical structure of primary precursor and controlling synthesis parameters, sol-gel technique provides nano-sized crystalline materials with high level of chemical purity and photocatalytic activity [3-12]. In this research, $\mathrm{TiO}_{2}$ catalysts synthesized by sol-gel technique were modified by adding metal to implement the utilization ability of isoproturon degradation under visible light. According to some prior researches, Mo assists in reducing the recombination of photogenerated charge carries, while $\mathrm{Mn}$ has the ability to reduce the band gap energy. Therefore, this work was interested in modifying $\mathrm{TiO}_{2}$ with co-loading of transition metals, molybdenum $(\mathrm{Mo})$ and manganese (Mn), to enhance high photocatalytic activity relating with promoting organic substances removal including isoproturon.

\section{Materials and Methods}

\subsection{Catalysts Preparation}

All catalysts were synthesized by sol-gel method using dissolved titanium (IV) isopropoxide (TTIP) in ethanol. The undoped $\mathrm{TiO}_{2}$ was prepared by $\left(\mathrm{C}_{12} \mathrm{H}_{28} \mathrm{O}_{4} \mathrm{Ti}\right)$ dissolving titanium (IV) isopropoxide (TTIP) in ethanol and adding $\mathrm{HCl}$ with some distilled water under vigorously stirring at an ambient temperature. The samples were dried in the oven at $80{ }^{\circ} \mathrm{C}$ for $24 \mathrm{~h}$ and calcined at $500{ }^{\circ} \mathrm{C}$ for $3 \mathrm{~h}$ with a heating rate of $5^{\circ} \mathrm{C} / \mathrm{min}$. [12] While, in case of $\mathrm{Mo} / \mathrm{Mn}$ doped $\mathrm{TiO}_{2}, \mathrm{TiO}_{2}$ was in sol-gel form using titanium tetraisopropoxide (TTIP) dissolved in ethanol as a precursor with 0.5 and $1 \mathrm{wt} . \%$ surface deposition of Mo and $\mathrm{Mn}$ by adding molybdenum (V) chloride and Manganese (II) chloride tetrahydrate as precursors, respectively.

\subsection{Catalysts Characterization}

In this research, the crystal structures and phase compositions were analyzed using XRD using $\mathrm{CuK} \alpha$ radiation between the $2 \theta$ range of $20-80$ degrees with 2 degreel min. UV-Vis were carried out at the absorption wavelength of $240 \mathrm{~nm}$ to measure the remaining concentration of isoproturon. For catalysts powder, UVVis were performed to measure the light absorption with visible wavelength from 200 to $800 \mathrm{~nm} . \mathrm{N}_{2}$ adsorption was applied to measure BET surface area with firstly pretreated in helium gas flow of $50 \mathrm{ml} / \mathrm{min}$ at $180^{\circ} \mathrm{C}$ for 4 h. In order to observe the catalysts surface, SEM were carried out at 2500X magnification. The electrons-holes recombination rate of all doped- $-\mathrm{TiO}_{2}$ and undoped were determined by PL spectra measurement with the excitation wavelength at $330 \mathrm{~nm}$.

\subsection{Photodegradation of Isoproturon under Visible Light}

In the photocatalytic degradation, 0.3 g photocatalyst from sol-gel method was added to $200 \mathrm{ml}$ of $10 \mathrm{ppm}$ isoproturon. The reaction mixture was stirred for $4 \mathrm{~h}$ using four $45 \mathrm{~W}$ lamps as a visible light source (total light intensity equal to 12000 lumen) and samples were collected every 20 minutes until $4 \mathrm{~h}$. The catalysts were then centrifuged to remove from the remaining isoproturon solution. Finally, the residual concentration of isoproturon solution was measured using the UV-Visible Spectroscopy (UV-vis) at the wavelength of $240 \mathrm{~nm}$ to further calculate the degradation percentage.

\section{Results and Discussion}

\subsection{Characterization Results}

Table 1 showed the results of BET characterization such as surface area $\left(\mathrm{m}^{2} / \mathrm{g}\right)$, mean pore diameter $(\mathrm{nm})$. According to the table, the surface areas of all doped $\mathrm{TiO}_{2}$ are larger than that of the undoped $\mathrm{TiO}_{2}$. The addition of metal leads to an increase of the surface area and a decrease of the mean pore diameter. In case of Mo ions, the specific surface area increased upon the incorporation of Mo since the similarity of $\mathrm{Mo}^{5+}$ and $\mathrm{Mo}^{6+}$ ionic radii with $\mathrm{Ti}^{4+}$ so that they possibly embed into the $\mathrm{TiO}_{2}$ crystal lattice by isomorphous substitution [13]. For Mn loading, an increase of BET surface area upon the undoped $\mathrm{TiO}_{2}$ might be caused from more fraction of micropore structure [14]. However, a decreasing of BET surface area with the higher $\mathrm{Mn}$ loading is possible due to an incorporation of $\mathrm{Mn}$ ions into $\mathrm{TiO}_{2}$ lattice preserving the anatase phase because of the influence of $\mathrm{Mn}$ charge of ionic radius [15]. This can be confirmed with XRD results that a decrease in crystalline size of anatase $\mathrm{TiO}_{2}$ in Table 2. From Table 1, the pore diameter of the $\mathrm{Mo} / \mathrm{Mn}-\mathrm{TiO}_{2}$ catalysts were smaller than those of undoped $\mathrm{TiO}_{2}$. However, the mesopores in $\mathrm{TiO}_{2}$ still appear after doping 
both Mo and Mn, creating efficiently photocatalytic reaction [16-18]. Among others, the single doped of $\mathrm{Mn}$ $0.5 \mathrm{wt} \%$ results in larger surface area surface at $57.98 \mathrm{~m}^{2} / \mathrm{g}$ with the mean pore diameter at $8.12 \mathrm{~nm}$. The co-doped of $0.5 \mathrm{wt} \%$ Mo and Mn provide the largest surface area when compared with other co-doped $\mathrm{TiO}_{2}$.

Table 1. BET surface area and pore size of Mo and Mndoped $\mathrm{TiO}_{2}$.

\begin{tabular}{lcc}
\hline Catalyst samples & $\begin{array}{c}\text { BET surface } \\
\text { area }\left(\mathbf{m}^{2} / \mathbf{g}\right)\end{array}$ & $\begin{array}{c}\text { Mean pore } \\
\text { diameter } \\
(\mathbf{n m})\end{array}$ \\
\hline Undoped $\mathrm{TiO}_{2}$ & 33.99 & 11.10 \\
Mo $0.5 \mathrm{wt} \%$ & 36.99 & 9.71 \\
Mo $1 \mathrm{wt}^{0} \%$ & 53.16 & 7.96 \\
$\mathrm{Mn} 0.5 \mathrm{wt} \%$ & 57.98 & 8.12 \\
$\mathrm{Mn} 1 \mathrm{wt} \%$ & 54.6 & 7.53 \\
Mo:Mn $=0.5: 0.5 \mathrm{wt} \%$ & 34.96 & 10.20 \\
Mo:Mn $=1: 1 \mathrm{wt}^{0} \%$ & 47.14 & 9.04 \\
Mo:Mn $=0.5: 1 \mathrm{wt} \%$ & 39.92 & 9.71 \\
Mo:Mn $=1: 0.5 \mathrm{wt} \%$ & 49.13 & 8.06 \\
\hline
\end{tabular}

From XRD patterns in Fig. 1, the average crystalline size and phase compositions of $\mathrm{TiO}_{2}$ were calculated according to Debye-Scherrer equation [19] and SqurrMyers equation [20], respectively. From the results, the average crystalline size of the pure $\mathrm{TiO}_{2}$ in anatase phase was $17.72 \mathrm{~nm}$, shown in Table 2. After loading Mo and $\mathrm{Mn}$, anatase to rutile ratio increased when compared with undoped which significantly impacted on photocatalytic efficiency, corresponding with the isoproturon degradation results in further section. This confirms with the other research discovered that approximately $60 \%$ anatase and $40 \%$ rutile exhibits an optimal photocatalytic performance [21]. It is obvious that crystalline size of the anatase decreased with increasing amount of Mn/Mo [22]. This was corresponding with the previous research finding that $\mathrm{Mo}$ and $\mathrm{Mn}$ significantly reduce the crystalline size of $\mathrm{TiO}_{2}$ $[23,24]$.

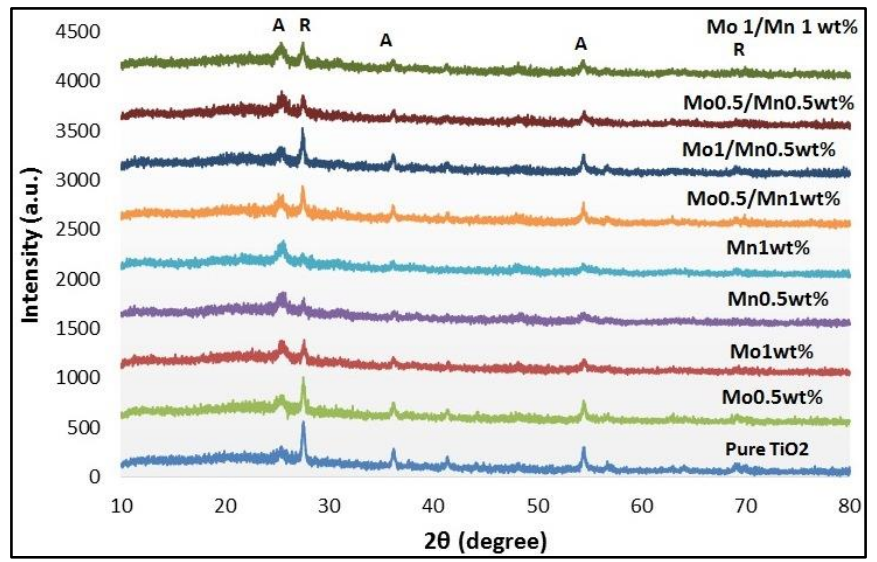

Fig. 1. XRD patterns of different $\mathrm{Mo} / \mathrm{Mn}$ doped- $-\mathrm{TiO}_{2}$ compared with the undoped $\mathrm{TiO}_{2}$.
Table 2. Average crystalline size and phase composition ( $\%$ anatase and rutile) of $\mathrm{Mo} / \mathrm{Mn}$ doped- $-\mathrm{TiO}_{2}$ compared with the undoped $\mathrm{TiO}_{2}$.

\begin{tabular}{lcccc}
\hline & \multicolumn{3}{c}{$\begin{array}{c}\text { Average } \\
\text { crystallite } \\
\text { size (nm) }\end{array}$} & \multicolumn{2}{c}{ Percent (\%) } \\
\cline { 2 - 5 } Catalyst samples & $\begin{array}{c}\text { Anata } \\
\text { se }\end{array}$ & $\begin{array}{c}\text { Rutil } \\
\text { e }\end{array}$ & $\begin{array}{c}\text { Anatas } \\
\text { e }\end{array}$ & $\begin{array}{c}\text { Rutil } \\
\text { e }\end{array}$ \\
\hline Undoped $\mathrm{TiO}_{2}$ & 17.72 & 14.50 & 24.73 & 75.27 \\
Mo 0.5 wt $\%$ & 16.40 & 17.31 & 28.94 & 71.06 \\
Mo 1 wt $\%$ & 16.46 & 21.78 & 43.55 & 56.45 \\
Mn 0.5 wt $\%$ & 12.55 & 10.62 & 56.94 & 43.06 \\
Mn 1 wt $\%$ & 11.30 & 12.73 & 58.83 & 41.17 \\
Mo:Mn=0.5:0.5wt $\%$ & 16.86 & 14.32 & 45.47 & 5453. \\
Mo:Mn=1:1wt $\%$ & 14.29 & 10.46 & 60.77 & 39.23 \\
Mo:Mn=0.5:1wt $\%$ & 16.71 & 17.32 & 64.41 & 35.59 \\
Mo:Mn=1:0.5wt $\%$ & 12.96 & 11.85 & 59.62 & 40.38 \\
\hline
\end{tabular}

Table 3. Band gap energy of $\mathrm{Mo} / \mathrm{Mn}$ doped on $\mathrm{TiO}_{2}$.

\begin{tabular}{lc}
\hline \multicolumn{1}{c}{ Catalyst samples } & $\begin{array}{c}\text { Band gap energy } \\
(\mathbf{e V})\end{array}$ \\
\hline Undoped $\mathrm{TiO}_{2}$ & 2.95 \\
$\mathrm{Mo} 0.5 \mathrm{wt} \%$ & 2.92 \\
$\mathrm{Mo} 1 \mathrm{wt} \%$ & 2.88 \\
$\mathrm{Mn} 0.5 \mathrm{wt} \%$ & 2.75 \\
$\mathrm{Mn} 1 \mathrm{wt} \%$ & 2.69 \\
$\mathrm{Mo:} \mathrm{Mn}=0.5: 0.5 \mathrm{wt} \%$ & 2.8 \\
$\mathrm{Mo:Mn}=1: 1 \mathrm{wt} \%$ & 2.64 \\
$\mathrm{Mo:Mn}=0.5: 1 \mathrm{wt} \%$ & 2.57 \\
$\mathrm{Mo:Mn}=1: 0.5 \mathrm{wt}^{\circ} \%$ & 2.71 \\
\hline
\end{tabular}

The band gap energy of each $\mathrm{TiO}_{2}$ was calculated based on Kubelka - Munk relationship [25], shown in Table 3. While comparing among single doped metal, $\mathrm{Mn}$ $0.5 \mathrm{wt} \%$ doped $-\mathrm{TiO}_{2}$ has smaller band gap energy $(2.75 \mathrm{eV})$ than $\mathrm{Mo} 0.5 \mathrm{wt} \%$ doped $-\mathrm{TiO}_{2}(2.92 \mathrm{eV})$ and the undoped $\mathrm{TiO}_{2}(2.95 \mathrm{eV})$. These results confirmed that type of doping metal influences on the light absorption: doping Mn provides further shift to more visible wavelength when compared with Mo [26]. The loading amount also significantly influences on narrower the band gap energy since the higher the metal loading, the smaller the bandgap energy [27]. All co-doped catalysts provide smaller band gap energy than the single metal-doped. Especially, Mo $0.5 / \mathrm{Mn} 1 \mathrm{wt} \%$ doped on $\mathrm{TiO}_{2}$ allocated the smallest band gap energy $(2.57 \mathrm{eV})$ among all $\mathrm{TiO}_{2}$ samples.

According to PL characterization in Fig. 2, doping the metals suppresses electrons-holes recombination rate since the defect-rich structural might be induced into $\mathrm{TiO}_{2}$, prolonging excitation lifetimes and boosting photocatalytic activity [28, 29]. From Fig. 2, co-doped of $\mathrm{Mo}$ and $\mathrm{Mn}$ at $1 \mathrm{wt} \%$ possesses the lowest recombination rate, corresponding to Fig. 4 as it achieved the most isoproturon degradation (37.8\%). 


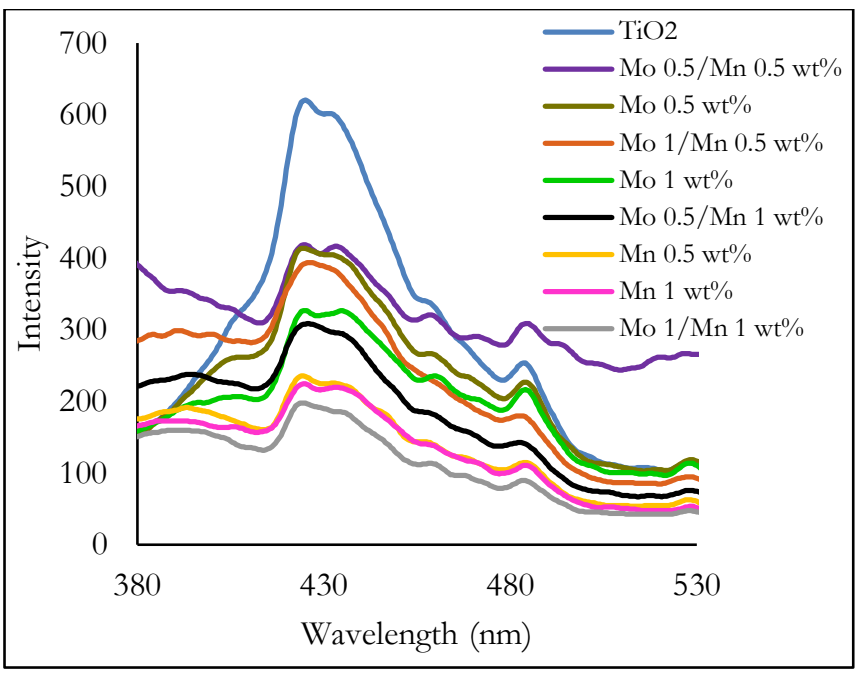

Fig. 2. Photoluminescence spectrum of undoped $\mathrm{TiO}_{2}$ and doped $\mathrm{TiO}_{2}$.
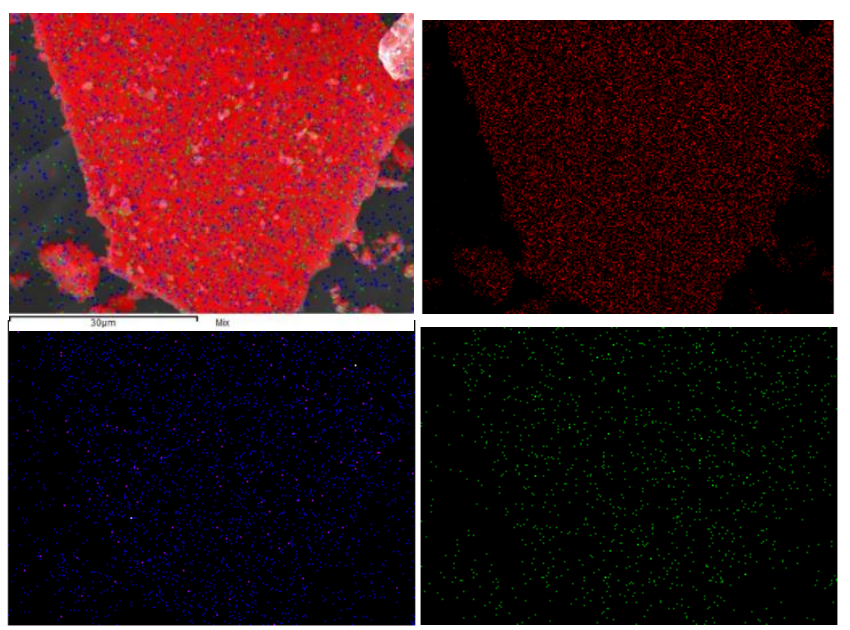

Fig 3. SEM mapping of $1 \%$ co-doping of Mo and Mn on $\mathrm{TiO}_{2}$ at $2500 \mathrm{X}$ magnification, red dots represent $\mathrm{Ti}$, blue dots represent Mo, and green dots represent Mn, respectively.

Moreover, the surface distribution of two doped metals at different doping amounts were also proved using SEM mapping. According to Fig. 3, Mo and Mn were welldispersed on $\mathrm{TiO}_{2}$ surface with an insignificant variation [30] (approximately \pm 0.07 from expected doping percentage).

\subsection{Results of Isoproturon Degradation}

The photocatalytic degradation of isoproturon using $\mathrm{TiO}_{2}$ follows the pseudo first-order linear reaction [31, 32]. The relationship between $-\ln \left(C_{A} / C_{A 0}\right)$ versus time is appeared to be linear, therefore the reaction rate constant ( $k$ value), shown in Table 4, can be calculated from Eq. (2).

Degradation rate of isoproturon is assumed to be equal to $\mathrm{R}_{\mathrm{A}}$,

$$
\begin{aligned}
& \mathrm{R}_{A}=-d C_{A} / d t \\
& -\ln \left(C_{A} / C_{A 0}\right)=k t t
\end{aligned}
$$

While $C_{A}$ is equal to the remaining concentration of isoproturon measured by UV-Vis, and $C_{A 0}$ is equal to an initial concentration of isoproturon.

Table 4. Initial reaction rate constant of various $\mathrm{TiO}_{2}$ catalysts in photodegradation of isoproturon under visible light.

\begin{tabular}{lc}
\hline \multicolumn{1}{c}{ Catalyst samples } & $\begin{array}{c}\text { Reaction rate constant } \\
\left(\mathbf{m i n}^{-1} \text { ) }\right.\end{array}$ \\
\hline Undoped $\mathrm{TiO}_{2}$ & 0.00051 \\
$\mathrm{Mo} 0.5 \mathrm{wt} \%$ & 0.00108 \\
$\mathrm{Mo} 1 \mathrm{wt} \%$ & 0.00107 \\
$\mathrm{Mn} 0.5 \mathrm{wt} \%$ & 0.00143 \\
$\mathrm{Mn} 1 \mathrm{wt} \%$ & 0.00124 \\
$\mathrm{Mo}: \mathrm{Mn}=0.5: 0.5 \mathrm{wt} \%$ & 0.00161 \\
$\mathrm{Mo}: \mathrm{Mn}=1: 1 \mathrm{wt} \%$ & 0.00167 \\
Mo: $\mathrm{Mn}=0.5: 1 \mathrm{wt} \%$ & 0.00129 \\
Mo: $\mathrm{Mn}=1: 0.5 \mathrm{wt} \%$ & 0.00180 \\
\hline
\end{tabular}

From Table 4, doping Mo and Mn delivered the faster degradation kinetic as implied by an increase of reaction rate constant with the higher doping amount. Also, Mo and $\mathrm{Mn}$ co-doping exhibited the synergistic effect as they both together activate in isoproturon degradation, leading to higher reaction rate constant when compared with single-metal doping. Though Mo $1 \mathrm{wt} \%$ - Mn $0.5 \mathrm{wt} \%$ has the greatest accelerating the photocatalytic degradation of isoproturon due to its highest initial reaction rate constant, its degradation rate was more decline after 2 hours passed when compared to that of $1 \mathrm{wt} \%$ co-doped $\mathrm{Mo}$ and $\mathrm{Mn}$ on $\mathrm{TiO}_{2}$. Therefore, $1 \mathrm{wt} \%$ co-doped $\mathrm{Mo}$ and $\mathrm{Mn}$ on $\mathrm{TiO}_{2}$ showing the maximum isoproturon degradation, which was equal to $37.8 \%$ for 4 hours reaction time, presented in Fig 4.

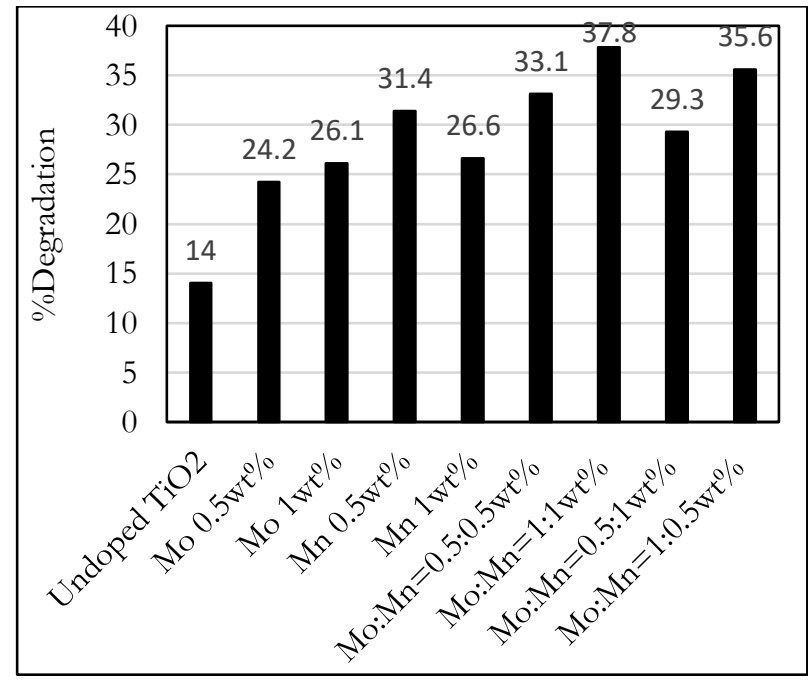

Fig. 4. \%Degradation of isoproturon after $4 \mathrm{~h}$ under visible light. 
Relating to UV-Vis, BET and PL results, doping Mo and $\mathrm{Mn}$ on $\mathrm{TiO}_{2}$ enhances the photocatalytic activity by narrowing the band gap energy, increasing surface area and reducing the recombination rate of electrons and holes. However, there is a threshold limit for decreasing band gap energy as this leads to an increase in electronsholes recombination rate and destructive the photocatalytic efficiency [33], corresponding with the case of $\mathrm{Mo} 0.5 \mathrm{wt} \%$ and $\mathrm{Mn} 1 \mathrm{wt} \%$ on $\mathrm{TiO}_{2}$ (shown in PL results from Fig. 2 and band gap calculation from Table 3).

\section{Conclusions}

In this research, Mo and $\mathrm{Mn}$ codoped- $\mathrm{TiO}_{2}$ have successfully been prepared using sol-gel method. The loading metal has significant influence on the photocatalytic activity, surface area, phase composition, crystalline size, band gap energy, and electrons-holes recombination. After $\mathrm{Mo}$ and $\mathrm{Mn}$ addition on $\mathrm{TiO}_{2}$, they both decrease the band gap energy and reduce the electrons-holes recombination when compared with single metal-doped and undoped $\mathrm{TiO}_{2}$. In summary, Mo and $\mathrm{Mn}$ have synergistic effect on isoproturon degradation under visible light irradiation. The highest photocatalytic activity in isoproturon photodegradation $(37.8 \%)$ belongs to $1 \mathrm{wt} \%$ co-doped Mo and $\mathrm{Mn}$ on $\mathrm{TiO}_{2}$, as its high surface area, high anatase to rutile ratio, small band gap energy, and low electrons-holes recombination. In case of Mo ions, the specific surface area increased upon the incorporation of Mo since the similarity of $\mathrm{Mo}^{5+}$ and $\mathrm{Mo}^{6+}$ ionic radii with $\mathrm{Ti}^{4+}$ so that they possibly embed into $\mathrm{TiO}_{2}$ crystal lattice by isomorphous substitution [13] which based on the main function of molybdenum in inhibiting the crystal coalescence, presented in another previous research [34]. However, for Mn loading, and an increase of BET surface area upon the undoped $\mathrm{TiO}_{2}$ might be caused from more fraction of micropore structure [14]. Both Mo and Mn support on the function increasing of $\mathrm{TiO}_{2}$ surface area, and also reduce the possibility of electrons-holes recombination.

This work is reasonably advantageous for further $\mathrm{TiO}_{2}$ development as it confirms the synergistic of codoping of two transition metals on titanium dioxide and also provides an alternative for waste water treatment, especially in case of pesticides removal in agricultural sites.

\section{Acknowledgement}

This research was financially and instrumentally supported by Department of Chemical Engineering, Faculty of Engineering and Industrial Technology, Silpakorn University, Nakhon Pathom, 73000, Thailand

\section{References}

[1] World Health Organization, "Guidelines for drinking-water quality," in Health Criteria and Other Supporting Information. 1996.
[2] Q. R. Deng, X. H. Xia, M. L. Guo, Y. Gao, and G. Shao, "Mn-doped $\mathrm{TiO}_{2}$ nanopowders with remarkable visible light photocatalytic activity," Materials Letters, vol. 65, no. 13, pp. 2051-2054, 2011.

[3] C. Su, B. -Y. Hong, and C. -M. Tseng, "Sol-gel preparation and photocatalysis of titanium dioxide," Catalysis Today, vol. 96, pp. 119-126, 2004.

[4] V. D. Binas, K. Sambani, T. Maggos, A. anKatsanaki, and G. Kiriakidis, "Synthesis and photocatalytic activity of $\mathrm{Mn}$-doped $\mathrm{TiO}_{2}$ nanostructured powders under UV and visible light," Applied Catalysis B: Environmental, vol. 113, pp. 79-86, 2012.

[5] M. A. Behnajady, H. Eskandarloo, N. Modirshahla, and M. Shokri, "Investigation of the effect of sol-gel synthesis variables on structural and photocatalytic properties of $\mathrm{TiO}_{2}$ nanoparticles," Desalination, vol. 278, no. 1-3, pp. 10-17, 2011.

[6] R. Chauhan, A. Kumar, and R. P. Chaudhary, "Structural and photocatalytic studies of Mn doped $\mathrm{TiO}_{2}$ nanoparticles," Spectrochim Acta A Mol Biomol Spectrosc, vol. 98, pp. 256-64, 2012.

[7] H. Khan and D. Berk, "Characterization and mechanistic study of $\mathrm{Mo}^{+6}$ and $\mathrm{V}^{+5}$ codoped $\mathrm{TiO}_{2}$ as a photocatalyst," Journal of Photochemistry and Photobiology A: Chemistry, vol. 294(Supplement C), pp. 96-109, 2014.

[8] K. Umar, M. M. Haque, M. Muneer, T. Harada, and M. Matsumura, "Mo, $\mathrm{Mn}$ and $\mathrm{La}$ doped $\mathrm{TiO}_{2}$ : Synthesis, characterization and photocatalytic activity for the decolourization of three different chromophoric dyes," Journal of Alloys and Compounds, vol. 578, pp. 431-438, 2013.

[9] S. Wang, L. N. Bai, H. M. Sun, Q. Jiang, and J. S. Lian, "Structure and photocatalytic property of Modoped $\mathrm{TiO}_{2}$ nanoparticles," Powder Technology, vol. 24, pp. 9-15, 2013.

[10] Y. Xu, B. Lei, L. Guo, W. Zhou, and Y. Liu, "Preparation, characterization and photocatalytic activity of manganese doped $\mathrm{TiO}_{2}$ immobilized on silica gel," Journal of Hazard Materials, vol. 160, no. 1, pp. 78-82, 2008.

[11] R. Akbarzadeh and S. Javadpour, "W/Mo-doped $\mathrm{TiO}_{2}$ for photocatalytic degradation of methylene blue," International Journal of Engineering Science and Innovative Technology, vol. 3, no. 4, pp. 621-629, 2014.

[12] V. Loryuenyong, K. Angamnuaysiri, J. Sukcharoenpong, and A. Suwannasri, "Sol-gel derived mesoporous titania nanoparticles: Effects of calcination temperature and alcoholic solvent on the photocatalytic behaviour," Ceramics International, vol. 38, no. 3, pp. 2233-2237, 2012.

[13] M. Cui, S. Pan, Z. Tang, X. Chen, X. Qiao, and $\mathrm{Q}$. Xu, "Physiochemical properties of $\mathrm{n}-\mathrm{n}$ heterostructured $\mathrm{TiO}_{2} / \mathrm{Mo}-\mathrm{TiO}_{2}$ composites and their photocatalytic degradation of gaseous toluene," Chemical Speciation and Bioavailability, vol. 29, no. 1, pp. 60-69, 2017.

[14] X. Ma, W. Zhou, and Y. Chen, "Structure and photocatalytic properties of $\mathrm{Mn}$-doped $\mathrm{TiO}_{2}$ loaded on wood-based activated carbon fiber composites," 
Materials, vol. 10, p. 631, 2017, doi: $10.3390 / \mathrm{ma1} 0060631$.

[15] P. Junlabhut and P. Nuthongkum, "Structural and optical properties of co-precipitation Mn-doped $\mathrm{TiO}_{2}$ nanoparticles," Thai Journal Nanotechnology, vol. 1, no. 1, pp. 1-7, 2016.

[16] C. Li, S. Yu, H. Dong, C. Liu, H. Wu, H. Che, and G. Chen, "Z-scheme mesoporous photocatalyst constructed by modification of $\mathrm{Sn}_{3} \mathrm{O}_{4}$ nanoclusters on $\mathrm{g}_{-} \mathrm{C}_{3} \mathrm{~N}_{4}$ nanosheets with improved photocatalytic performance and mechanism insight," Applied Catalysis B: Environmental, vol. 238, no. 15, pp. 284 293, 2018.

[17] Y. Castro, N. Arconada, and A. Duran, "Synthesis and photocatalytic characterization of mesoporous $\mathrm{TiO}_{2}$ films doped with Ca, W and N," Bulletin of the Spanish Society of Ceramics and Glass, vol. 54, no. 1, pp. 11-20, 2015.

[18] B. Niu, X. Wang, K. Wu, X. He, and R. Zhang, "Mesoporous titanium dioxide: synthesis and applications in photocatalysis, energy and biology," Materials, vol. 11, no. 10, p. 1910, 2018, doi: 10.3390/ma11101910.

[19] K. M. Reddy, S. V. Manorama, and A. R. Reddy, "Bandgap studies on anatase titanium dioxide nanoparticles," Materials Chemistry and Physics, vol. 78, no. 1, pp. 239-245, 2003.

[20] D. A. Torres, F. Gordillo-Delgado, and J. PlazasSaldaña, "Formation of $\mathrm{TiO}_{2}$ nanostructure by plasma electrolytic oxidation for $\mathrm{Cr}(\mathrm{VI})$ reduction," Journal of Physics: Conf. Series, vol. 786, p. 012046, 2017.

[21] R. Su, R. Bechstein, L. So, R. T. Vang, M. Sillassen, B. Esbjornsson, A. Palmqvist, and F. Besenbacher, "How the anatase-to-rurile ratio influences the photoactivity of $\mathrm{TiO}_{2}$," Journal of Physical Chemistry C, vol. 115, no. 49, pp. 24287-24292, 2011.

[22] D. A. H. Hanaor and C. C. Sorrell, "Review of the anatase to rutile phase transformation," Journal of Materials Science, vol. 46, no. 4, pp. 855-874, 2011.

[23] M. R. Saidur, A. R. Abdul Aziz, and W. J. Basirum, "Synthesis, characterization and electrochemical study of $\mathrm{Mn}$-doped $\mathrm{TiO}_{2}$ decorated polypyrrole nanotubes," IOP Conference Series: Materials Science and Engineering, vol. 210, p. 012009, 2017, doi: 10.1088/1757-899X/210/1/012009.

[24] Q. Deng, X. H. Xia, M. Guo, Y. Gao, and G. Shao, "Mn-doped TiO2 nanopowders with remarkable visible light photoactivity," Materials Letters, vol. 65, no. 13, pp. 2051-2054, 2011.
[25] J. S. Lee, H. K. You, and C. B. Park, "Highly photoactive, low bandgap $\mathrm{TiO}_{2}$ nanoparticles wrapped by graphene," Advance Materials Communication, vol. 24, no. 8, pp. 10841088, 2012.

[26] M. Lesnik, D. Verhovsek, N. Veronovski, M. Gracner, G. Drazic, K. Z. Soderznik, and M. Drofenik, "Hydrothermal synthesis of $\mathrm{Mn}$ - doped $\mathrm{TiO}_{2}$ with a strongly suppressed photocatalytic activity," Materials and Technology, vol. 52, no. 4, pp. 411-416, 2018.

[27] Z. Dargahi, H. Asgharzadeh, and H. Maleki-Ghaleh, "Synthesis of Mo-doped $\mathrm{TiO}_{2} /$ reduced graphene oxide nanocomposite for photoelectrocatalytic applications," Ceramics International, vol. 44, pp. 13015-13023, 2018.

[28] W. Xie, R. Li, and Q. Yu, "Enhanced photocatalytic activity of Se-doped $\mathrm{TiO}_{2}$ under visible light irradiation," Scientific Reports, vol. 8, no. 1, 2018, doi: 10:1038/s41598-018-27135-4.

[29] W. Choi, J. Y. Choi, and H. Song, "Regulation of electron-hole recombination kinetics on uniform metal-semiconductor nanostructures for photocatalytic hydrogen evolution," APL Materials, vol. 7, p. 100702, 2019, doi: 10.1063/1.5099666.

[30] R.-G. Ciocarlan, E. M. Seftel, M. Mertens, A. Pui, M. Mazaj, N. N. Tusar, and P. Cool, "Novel magneticnanocomposites containing quaternary ferrites systems $\mathrm{Co}_{0.5} \mathrm{Zn}_{0.25} \mathrm{M}_{0.25} \mathrm{Fe}_{2} \mathrm{O}_{4}(\mathrm{M}=\mathrm{Ni}, \mathrm{Cu}, \mathrm{Mn}, \mathrm{Mg})$ and $\mathrm{TiO}_{2}$ anatase phase a $\mathrm{s}$ photocatalysts for wastewater," Materials Science and Engineering: B, vol. 230, pp 1-7, 2018.

[31] A. Verma, N. T. Prakash, and A. P. Toor, "Photocatalytic degradation of herbicide isoproturon in $\mathrm{TiO}_{2}$ aqueous suspensions: study of reaction intermediates and degradation pathways," AIChE: Environmental Progress and Sustainable Energy, vol. 33, no. 2, 2014, DOI: 10.1002/ep.11799.

[32] S. Thomas, A. Alatrche, M.-N. Pons, and O. Zahraa, "Degradation of herbicide isoproturon by a photocatalytic process," Comptes Rendus Chimie, vol. 17, no. 7-8, pp. 824-831, 2014.

[33] J. Moma and J. Baloyi, "Modified titanium dioxide for photocatalytic applications," in PhotocatalystsApplications and Attributes. 2018, doi: 10.5772/ intechopen.79374.

[34] O. Karslioglu, X. Song, H. Kuhlenbeck, and H. -J. Freund, "Mo+ $\mathrm{TiO}_{2}$ (110) mixed oxide layer: structure and reactivity," Topics in Catalysis, vol. 56, no. 15-17, pp. 1389-1403, 2013, DOI $10.1007 / \mathrm{s} 11244-013-0142-\mathrm{y}$. 
Yada Yakob, photograph and biography not available at the time of publication.

Kanjana Naknun, photograph and biography not available at the time of publication.

Parichat Hirunmas, photograph and biography not available at the time of publication.

Paul Egwuonwu Dim, photograph and biography not available at the time of publication.

Mutsee Termtanun, photograph and biography not available at the time of publication. 